\title{
Formation of very young colonies by Phaeocystis pouchetii from western Norway
}

\author{
P. G. Verity ${ }^{1, *}$, M. J. Zirbel ${ }^{2}$, J. C. Nejstgaard ${ }^{3}$ \\ ${ }^{1}$ Skidaway Institute of Oceanography, 10 Ocean Science Circle, Savannah, Georgia 31411, USA \\ ${ }^{2}$ College of Oceanic and Atmospheric Sciences, Oregon State University, Corvallis, Oregon 97331-5503, USA \\ ${ }^{3}$ Department of Biology, University of Bergen, PO Box 7800, 5020 Bergen, Norway
}

\begin{abstract}
The marine phytoplankton species Phaeocystis pouchetii often forms large blooms of gelatinous colonies during spring in north temperate, boreal, and Arctic waters. The macroscopic colonies in such blooms develop originally from free-swimming solitary cells that shed their flagella, secrete a gelatinous membrane, and undergo repeated cell divisions within an enlarging colony membrane. However, the essential first steps in this process have not been described in situ, and hence the factors controlling initiation of colony blooms are poorly understood. Studies were conducted in mesocosms in a western Norway fjord to document the development of small young colonies under simulated and ambient conditions, resulting in 2 novel perspectives: (1) The critical early stages of colony bloom formation may occur in a relatively brief window in time. The rate of formation of young colonies from solitary cells was faster in nutrient-fertilized compared to unfertilized mesocosms, but this only happened after a period of diatom growth in the mesocosms and subsequent increases in $P$. pouchetii colony abundance. Then, small percentages of solitary cells were mathematically necessary to account for observed colony numbers. (2) Initial formation of new young colonies occurred during the dark period of the ambient springtime diel light cycle, and patterns of colony accumulation implied rapid multiple cell divisions within colonies during the dark period, a process termed phased ultradian growth. Such an evolutionary strategy of rapid change from single cells to multi-cell colonies would be advantageous as a means of minimizing grazing losses during the critical period of size transition from microscopic free-swimming cells that are susceptible to microzooplankton and viruses, to larger colonies that are susceptible to metazoan zooplankton but relatively impervious to viruses and microzooplankton. The combined results offer a new insight into colony proliferation: colony blooms do not necessarily require a long period of constant conversion of solitary cells into colonies, but rather may be the product of punctuated, rapid life cycle transformations and ultradian growth of young colonies.
\end{abstract}

KEY WORDS: Phaeocystis pouchetii · Phytoplankton ecology · Colony formation · Ultradian growth · Evolutionary strategy $\cdot$ Mesocosms

Resale or republication not permitted without written consent of the publisher

\section{INTRODUCTION}

Phaeocystis spp. are well known for the spatially and temporally extensive blooms of its colonial life cycle stage, which are commonplace in many cold-water temperate, boreal, and high latitude waters (Lancelot et al. 1994, Schoemann et al. 2005). Indeed, early attention was focused on this genus because of its ability to clog even coarse collection devices such as plankton nets and fishermen's nets (Savage 1930,
Boalch 1984). However, this macroscopic stage develops from microscopic free-living cells, which can individually lose their flagella, secrete a gelatinous sheath, and subsequently multiply within the colony membrane as the colony increases in size (reviewed in Rousseau et al. 1994, 2007). In northern hemisphere species, the colony membrane and morphology can be mostly spherical and highly elastic as in P. globosa (van Rijssel et al. 1997, Hamm 2000), or typically lobate and thought to be more fragile as in P. pouchetii, and thus 
more susceptible to mesozooplankton grazing (Baumann et al. 1994, Jacobsen 2002, reviewed in Nejstgaard et al. 2007). However, colony morphology can vary considerably within each Phaeocystis species for reasons that are unknown, and there is also recent evidence of changes in morphology of individual $P$. pouchetii colonies, which was associated with development of motility of colony cells and their subsequent emigration from colonies (Whipple et al. 2007). Thus, while colonies develop from solitary cells, mechanistic relationships between the 2 life cycle stages are poorly understood.

The large colonies that are visible to the naked eye develop primarily from very small colonies containing few cells, typically in the geometric sequence of 1-, 2-, $4-$, and 8-cell colonies etc., and caused by cell division which is often synchronous within a colony. Another means of colony multiplication is occasionally seen in larger colonies, which can divide into 2 smaller 'daughter colonies' (Whipple et al. 2005), but it is unknown how this phenomenon compares quantitatively to the formation of colonies from solitary cells. This latter life cycle sequence has been reported from culture studies of Phaeocystis globosa and P. pouchetii (reviewed in Rousseau et al. 2007), and is assumed to be representative of the dominant vegetative growth pattern for natural populations, but has seldom been quantified in situ. There could be several explanations for the shortage of information on the early rates of colony initiation in nature, including (1) the youngest

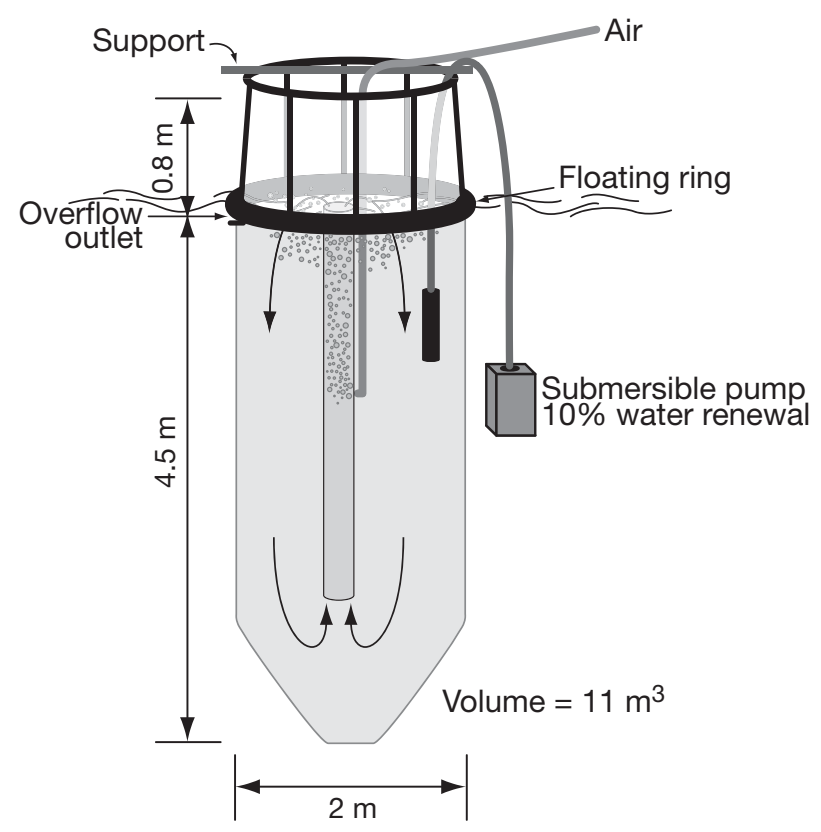

Fig. 1. Schematic diagram of the mesocosms used in this study. See 'Materials and methods' for details colonies are easily missed due to their small size, low contrast, and numerical low abundance; (2) young colonies may be formed primarily at night (i.e. they may be missed by routine day-oriented sampling); and (3) young colonies may not spend much time in between cell division stages. Accordingly, the roles of exogenous and endogenous factors in life cycle transitions of Phaeocystis are poorly understood.

As part of an intensive study of Phaeocystis pouchetii dynamics in mesocosms at the University of Bergen's marine field station, Norway (Whipple et al. 2005, Alderkamp et al. 2006, Nejstgaard et al. 2006), experiments and sampling were conducted during spring in 2 consecutive years (March 4 to 24, 2002, and February 27 to April 2, 2003). The studies reported here focused on rates and timing of new colony formation during the early stages of life cycle transformation from solitary cells to colonies.

\section{MATERIALS AND METHODS}

The samples and experimental plankton communities in the present study were derived from 2 transparent polyethylene mesocosms ( $4.5 \mathrm{~m}$ deep, $2 \mathrm{~m}$ diameter, ca. $11 \mathrm{~m}^{3}, 90 \%$ photosynthetically active radiation: Fig. 1), which were set up in Raunefjorden at the Norwegian National Mesocosm Center, located at the Marine Biological field station at the University of Bergen in western Norway $\left(60^{\circ} 16^{\prime} \mathrm{N}, 05^{\circ} 14^{\prime} \mathrm{E}\right)$ between February 27 and April 2, 2003. Additional details concerning the mesocosm facility can be found at www.bio.uib.no/lsf/inst2.html. In both the present study and in the previous year, nutrient amendments (described below) resulted in nearly monospecific blooms of colonial Phaeocystis pouchetii (Nejstgaard et al. 2006); however, daily sampling conducted during mid-morning did not reveal many young small colonies, and hence it was uncertain where the larger colonies originated.

The mesocosms were filled in situ by pumping unfiltered fjord water from $5 \mathrm{~m}$ depth using a large submersible centrifugal pump, specially designed to minimally damage live plankton, with a flow rate of ca. $1.5 \mathrm{~m}^{3} \mathrm{~min}^{-1}$ (ITT Flycht A/S, model 3085-182). The individual mesocosms were filled in a staggered sequential fashion such that all filling was completed within $1 \mathrm{~h}$. The mesocosms were mixed thoroughly using an airlift-system that re-circulated the entire volume ca. 5 times d ${ }^{-1}$ (ca. $40 \mathrm{l} \mathrm{min}^{-1}$ : Jacobsen et al. 1995). In each mesocosm, $10 \%$ of the water was renewed daily with fjord water (from ca. $2.5 \mathrm{~m}$ ) using submersible aquarium pumps: this allowed for the introduction of new species, prevented substantial $\mathrm{pH}$ changes, and replaced water removed for sampling 
(see also Egge 1993 and Williams \& Egge 1998 for additional discussion).

In the present study, 2 mesocosms, differing significantly from each other in their nutrient histories, were sampled. One was amended with nitrate $\left(\mathrm{NaNO}_{3}\right)$ and phosphate $\left(\mathrm{KH}_{2} \mathrm{PO}_{4}\right)$, corresponding to an initial enrichment of $16 \mu \mathrm{M}$ nitrate and $1 \mu \mathrm{M}$ phosphate by the addition of $100 \mathrm{ml}$ each of stock solutions of $\mathrm{NaNO}_{3}$ $(1.76 \mathrm{M})$ and $\mathrm{KH}_{2} \mathrm{PO}_{4}(0.11 \mathrm{M})$. Nutrients removed by the $10 \%$ water renewal were replaced daily by the addition of $10 \mathrm{ml}$ each of the nutrient stock solutions, equivalent to daily additions of $1.6 \mu \mathrm{M} \mathrm{NO}_{3}$ and $0.1 \mu \mathrm{M}$ $\mathrm{PO}_{4}$. The other mesocosm was left unamended and served as a control treatment. While the mesocosms were not replicated for logistical reasons, the nutrient treatments resulted in similar patterns of plankton community development, i.e. nearly monospecific blooms of Phaeocystis pouchetii colonies, when the approach was replicated in succeeding years (Nejstgaard et al. 2006). The mesocosms provided plankton communities of known histories for 2 types of experiments in the present study.

(1) Natural plankton communities from the 2 mesocosms were gravity-filtered on 2 dates through $47 \mathrm{~mm}$ diameter, $8 \mu \mathrm{m}$ pore size, polycarbonate filters. The resulting $\leq 8 \mu \mathrm{m}$ filtrates thus contained auto-, hetero-, and mixotrophic cells nominally $\leq 8 \mu \mathrm{m}$ in effective maximum size. The purpose of this screening was to eliminate all colonies, which was confirmed by careful pre-experimental microscopic assessment. Each of the mesocosm filtrates was used to fill the 24 wells $(2.5 \mathrm{ml}$ each well) in a sterile, acid-cleaned well plate (Nalge Nunc International). Well plates were incubated in a walk-in cold room at $5^{\circ} \mathrm{C}$ using simulated natural lighting (14:10 h light:dark) set to match ambient cycles. Light (day) periods began at 08:30 $\mathrm{h}$ and dark (night) periods at 22:30 h. Light levels during the light and dark periods averaged 62 and $8 \mu \mathrm{mol}$ photons $\mathrm{m}^{-2} \mathrm{~s}^{-1}$, respectively, and were measured using a hand-held QSL 100 light meter (Biospherical Instruments). Each well was examined daily for $7 \mathrm{~d}$ at 14:00 to 16:00 h local time, and the number of colonies per well were measured using a Leica MZ 9.5 zoom stereomicroscope. This procedure was followed for 2 identical experiments, one beginning on March 4 immediately after the mesocosms were filled, and the second on March 15, after the appearance of healthy populations of colonies in the nutrient amended mesocosm. The working hypothesis was that new young colonies would be formed in the 2 filtrates independent of their nutrient history.

(2) The second experiment consisted of detailed examination of freshly collected samples from the nutrient-amended mesocosm during the natural night period of March 21 to 22, 2003. The working hypothe- sis was that formation of new colonies occurred at night, and thus explained the absence of very young colonies noted in previous experiments and mesocosm samples. Samples (2 l) were collected by immersing polycarbonate bottles in the well-mixed mesocosm at 20:00, 00:00, 04:00, and 08:00 h, which corresponded to the period just before sunset, after dark (2 samples), and just after sunrise, respectively. Unconcentrated samples were examined immediately using a Sedgwick-Rafter 1-ml glass microscope slide and the maximum possible magnification of $40 \times$ (due to slide thickness and working distance of the microscope objectives) on a Nikon Diaphot inverted microscope. Very small colonies were rarely observed in these chambers, but the relatively low magnification optics, Sedgwick-Rafter slide thickness, and low colony concentrations limited confidence in the estimates, so samples were also prepared for subsequent epifluorescent (higher power) microscope examination. They were fixed with HPLC grade glutaraldehyde $(0.5 \%$ final concentration), and stained with proflavin (100 ng $\mathrm{ml}^{-1}$ final sample concentration, from stock concentration of $5.5 \mu \mathrm{g} \mathrm{ml}^{-1}$ ) and DAPI (25 $\mathrm{ng} \mathrm{ml}^{-1}$ final sample concentration, from stock concentration of $500 \mathrm{ng} \mathrm{ml}^{-1}$ ) as described by Haas (1982) and Porter \& Feig (1980), except that higher concentrations of stain were required to effectively stain Phaeocystis pouchetii cells. Three epifluorescent slides were made by gently filtering $10 \mathrm{ml}$ of the fixed and stained samples onto black $0.2 \mu \mathrm{m} 25 \mathrm{~mm}$ diameter polycarbonate filters using a hand-pump with $<0.5 \mathrm{~mm} \mathrm{Hg}$ vacuum pressure. Filters were mounted onto glass slides with a cover slip and stored at $-20^{\circ} \mathrm{C}$ until analysis. Colonies and their cell density were enumerated by epifluorescence microscopy using an Olympus BX-60 fluorescence microscope equipped with a $60 \times$ Planapo NA (numerical aperture) 1.40 oil objective.

The statistical packages SAS (v 8.0; SAS Institute) and SigmaStat (v 3.00; SPSS) were used for statistical analyses. Comparisons of cell and colony concentrations between and within mesocosms, and comparisons of growth rates, were conducted by ANOVA and $t$-tests. Significance was reported at either $95 \%$ confidence level $(p<0.05)$ or $99 \%$ ( $p<0.01)$.

\section{RESULTS}

In the $\leq 8 \mu \mathrm{m}$ incubation experiments, young colonies appeared at approximately linear rates in both experiments for the $7 \mathrm{~d}$ experimental periods (Fig. 2). In the first incubation, which began shortly after fertilization occurred (Fig. 2a: March 4 to 11, 2003), average colony formation rates in the fertilized and unfertilized mesocosms were $1.0 \pm 0.1$ and $1.1 \pm 0.1$ colonies $\mathrm{ml}^{-1} \mathrm{~d}^{-1}$, 


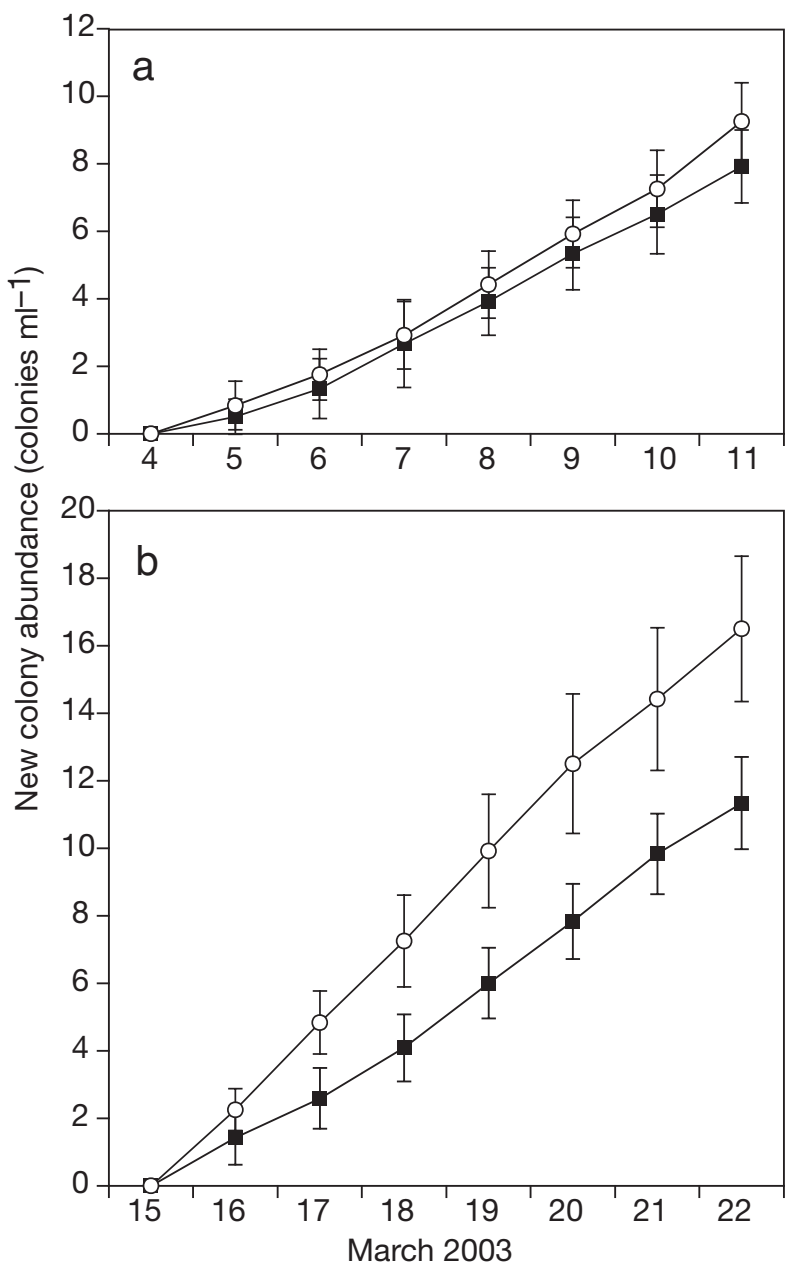

Fig. 2. (a) Time course of accumulation of new colonies growing in $\leq 8 \mu \mathrm{m}$ filtered water collected (a) March 4, 2003, and (b) March 15, 2003, from a control mesocosm (ם) and a nutrient fertilized mesocosm $(O)$, and incubated in well plates for $7 \mathrm{~d}$. See 'Results' for details

respectively, which were not different at the $\mathrm{p}<0.05$ level ( $t$-test). The concentrations of free-living solitary Phaeocystis pouchetii cells at the beginning of the incubations were 510 cells ml $^{-1}$ in the control $\leq 8 \mu \mathrm{m}$ filtrate, and 635 cells ml$^{-1}$ in the nutrient-amended $\leq 8 \mu \mathrm{m}$ filtrate.

In the second incubation (Fig. 2b: March 15 to 22), which began ca. 2 wk after fertilization and also after macroscopic colonies had appeared in the fertilized mesocosm, there were notable differences. Colonies were formed at significantly higher rates $(t$-test, $\mathrm{p}<$ 0.01 ) in the fertilized mesocosm (mean $=2.3 \pm 0.2$ colonies $\mathrm{ml}^{-1} \mathrm{~d}^{-1}$ ) compared to the unfertilized meso$\operatorname{cosm}\left(1.5 \pm 0.2\right.$ colonies $\left.\mathrm{ml}^{-1} \mathrm{~d}^{-1}\right)$. Both rates were significantly ( $t$-test, $p<0.05$ ) higher than those observed in the earlier experiment started just after fertilization. The concentrations of free-living solitary Phaeocystis pouchetii cells at the beginning of the incubations were 660 cells ml $^{-1}$ in the control $\leq 8 \mu \mathrm{m}$ filtrate, and 867 cells ml$^{-1}$ in the nutrient-amended $\leq 8 \mu \mathrm{m}$ filtrate.

In both $7 \mathrm{~d}$ incubation experiments, colonies were enumerated daily in early to mid-afternoon, and these were already colonies of $\geq 8$-cell. The absence of younger colonies with fewer cells in these experiments could have been due to the use of low magnification microscopy, or to the time of day if cell division was phased, which was the rationale for the nighttime mesocosm sampling study. The smallest and youngest colonies of Phaeocystis pouchetii are both numerically rare and visually unremarkable, i.e. they are small and relatively translucent objects that are difficult to see without staining (Cariou et al. 1994). Accordingly, care must be exercised to confirm that absence of evidence is not mistakenly inferred to be evidence of their absence, due to methodological limitations. Higher magnification examination (objectives of $60 \times$ or greater, with high NA) of samples, coupled with a microscopy protocol that increases colony visibility or contrast with background, is recommended.

In the overnight mesocosm sampling study, young colonies were found at all sample times during the night and early morning (Fig. 3). At the first sample time of 20:00 h (just before sunset), there were a total of 14 colonies $\mathrm{ml}^{-1}$ : 2-cell colonies were most abun-

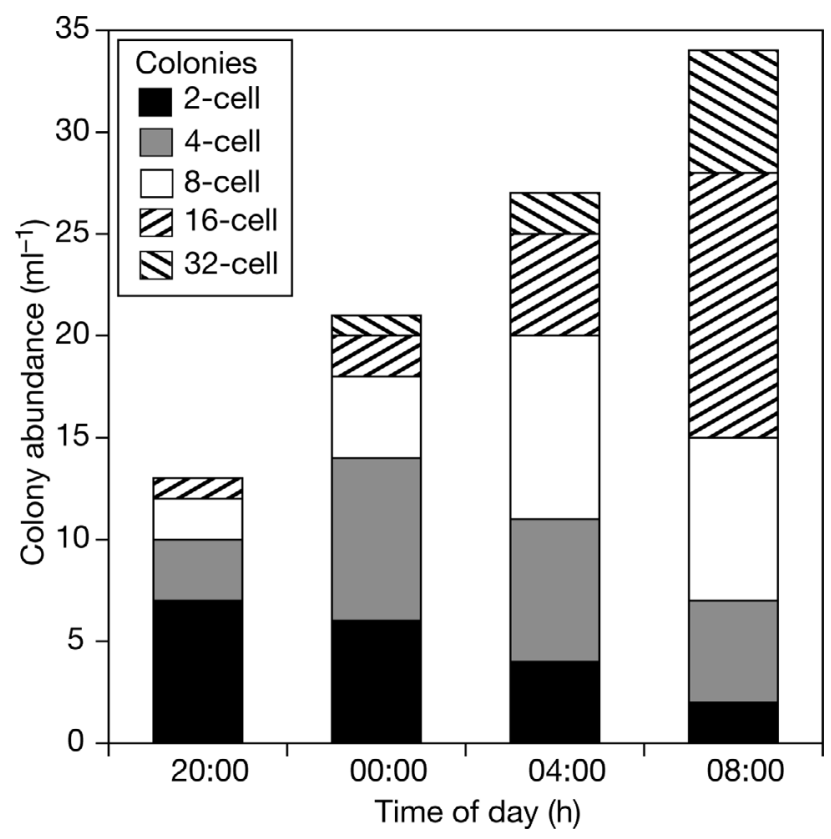

Fig. 3. Changes in mean concentration of young colonies in the fertilized mesocosm during the night of March 21-22, 2003. Samples were collected at $4 \mathrm{~h}$ intervals $(20: 00,00: 00$, 04:00 and 08:00 h), and number of colonies was determined in triplicate subsamples using epifluorescence microscopy, for each of 5 age classes: $2-, 4-, 8-, 16-$ and 32 -cell colonies 
dant, with some 4- and 8-cell colonies, and rare 16-cell colonies. The smallest colonies were significantly more abundant ( $t$-test, $\mathrm{p}<0.05$ ) than larger colonies. At 00:00 h (midnight), there were 21 colonies $\mathrm{ml}^{-1}$, most of which were 4 -cell colonies; 8- and 16-cell colonies had increased in abundance along with a few 32-cell colonies, while 2-cell colonies had declined. Four-cell colonies were significantly $(t$-test, $\mathrm{p}<0.05)$ more abundant than 8-, 16-, and 32-cell colonies, but not more numerous than 2-cell colonies. At 04:00 h, there were 27 colonies $\mathrm{ml}^{-1}$, mostly 8-cell colonies, with increasing concentrations of 16- and 32-cell colonies, and fewer 4and 2-cell colonies; 8-cell colonies were significantly more numerous than the other classes ( $t$-test, $\mathrm{p}<0.05)$. At 08:00 h (just after sunrise), there were 34 colonies $\mathrm{ml}^{-1}$, i.e. an increase of 20 colonies $\mathrm{ml}^{-1}$ in the $12 \mathrm{~h}$ sample window. The most abundant were the 16-cell colonies; 32-cell colonies had increased further in abundance, while 8-, 4-, and 2-cell colonies had declined further. Sixteen-cell colonies were significantly more numerous than the other size classes ( $t$-test, $\mathrm{p}<$ 0.05). Each colony size class generally increased in absolute and relative abundance until its peak and then declined thereafter, as cells within the colonies divided synchronously and the next colony size class became more abundant. This rate of increase is not strictly comparable to those in the $\leq 8 \mu \mathrm{m}$ well plate incubations because the latter were sampled at $24 \mathrm{~h}$ intervals and over longer periods (see 'Discussion').

\section{DISCUSSION}

The initiation of new colonies from free-living cells has been described from culture studies of Phaeocystis globosa (Cariou et al. 1994, Peperzak et al. 2000), and evidence supports the existence of a true haploiddiploid life cycle in this species (reviewed in Rousseau et al. 2007). P. pouchetii appears to include only diploid life cycle stages, but vegetative colony propagation from solitary cells previously derived from colonies is considered to be an essential step in the proliferation of its colony blooms (Jacobsen 2002, Rousseau et al. 2007). Another form of colony multiplication, in which mature colonies containing tens to hundreds of cells undergo colony budding or division, has also been documented for $P$. pouchetii and P. globosa (Verity et al. 1988, Rousseau et al. 1994, Whipple et al. 2005). However, this process mathematically appears to be of secondary importance to bloom formation, given the rapid rate of colony proliferation reported in situ.

The present study provides rates of formation of new colonies using $\leq 8 \mu \mathrm{m}$ plankton incubated in the absence of $>8 \mu \mathrm{m}$ grazers. Soon after the mesocosms had been filled and nutrient amendments initiated, the rate of formation of new colonies did not differ between control and unamended mesocosms (Fig. 2a). Eleven days later, new colonies were being formed at significantly higher rates in the fertilized compared to unfertilized mesocosm (Fig. 2b). More importantly, new colonies were formed in the fertilized mesocosm at twice the rate in the later experiment compared to the earlier one. Thus, the formation of colonies from solitary cells was not temporally constant. Since nutrient concentrations in the fertilized mesocosm at the times of the 2 experiments were similar (Nejstgaard et al. 2006), this suggests that some other aspect of the water or plankton community in the fertilized mesocosm was responsible for the increased formation of new colonies. Given the known role of diatom frustules as sites for colony formation, and the 1 to 2 order of magnitude increase in diatoms in the fertilized mesocosm during the time between the first and second experiments (Nejstgaard et al. 2006), it is tempting to attribute the difference to broken frustules $\leq 8 \mu \mathrm{m}$ in size which may have been present in the incubation vessels. However, the patterns in Fig. 2 may also reflect some other unknown aspect of the timing and regulation of life cycle phenomena, e.g. infochemicals, endogenous rhythms, or other induction mechanisms. Nevertheless, previous studies in these mesocosms showed that diatomaceous earth, which includes many particles $\leq 8 \mu \mathrm{m}$ in size, stimulated formation of new colonies (Nejstgaard et al. 2006). Young colonies are reported to use diatom frustules as attachment sites (Lancelot \& Rousseau 1994, Rousseau et al. 1994, Jacobsen 2002), but it is unknown whether suitable substrates limit in situ production of new colonies. Perhaps large diatom frustules even function to minimize ingestion of new small colonies by, e.g., protozooplankton. Young Phaeocystis pouchetii colonies have been observed attached to substrate (diatoms) through the 4 -cell stage $(\approx 15 \mu$ m diameter) and sometimes to 8-cells $(30 \mu \mathrm{m})$. Beginning with this stage, larger/older colonies (16-cell [50 $\mu \mathrm{m}$ ] and 32-cell [70 to $80 \mu \mathrm{m}$ ] colonies) are primarily or perhaps exclusively free-floating.

Despite the importance of colony initiation from freeliving cells, it is enigmatic nonetheless that only a small fraction of the latter are required to form colonies in order to account for observed rates of appearance of new colonies. For example, the rate of new colony appearance in Fig. 2 required only ca. $1 \%$ of free-living cells to form colonies, similar to experimental data from mesocosm studies the previous year (Nejstgaard et al. 2006). In the latter study, Phaeocystis pouchetii solitary cells added to the mesocosm from unialgal culture did not stimulate enhanced colony development. Hence the dominant fate for $P$. pouchetii solitary cells, at least in spring in western Norway, appears to be a trophic one rather than a life cycle transformation, 
The mesocosm nighttime sampling showed that Phaeocystis pouchetii populations, growing in a western Norwegian fjord in spring under ambient light, formed new colonies during the dark period of the natural diel light:dark cycle. The number of colonies and their cell density increased in a sequence that implied phased and perhaps multiple cell divisions during the night period. Such a growth pattern that includes multiple rounds of DNA replication is called ultradian growth, and has been recently reported for cultures and field samples of P. pouchetii and P. globosa (Jacobsen \& Veldhuis 2005, Veldhuis et al. 2005), as well as in other marine (Prochlorococcus: Shalapyonok et al. 1998) and freshwater genera (Euglena: Edmunds \& Funch 1969). Given that the sampled populations in this study were contained within mesocosms with only a $10 \%$ daily exchange with the external fjord water, it is reasonable to assume that the observed pattern represented processes occurring within the contained population, and was not due to changed size distributions caused by recently immigrated colonies. Changes in colony abundance therefore represent the balance of growth and loss processes within the mesocosms. While the sequence of increasing colony size and cell density undoubtedly reflected division of P. pouchetii cells within the colonies, there may also have been colony-size dependent loss processes acting to determine the observed net changes in colony size distribution. For example, if grazing pressure was greater on smaller colonies compared to larger (older) colonies, this would act to exacerbate the sequential pattern of initial appearance of small colonies followed by increasingly greater representation of larger colonies over time.

Nevertheless, the observed pattern was consistent with the notion that colonies underwent phased growth, whereby cell density within colonies increased during the dark period, perhaps with multiple cell divisions within individual colonies as observed in cultures (Veldhuis et al. 2005). Distinct advantages might accrue from this strategy for a colony-forming species with a heteromorphic life cycle. The colony membrane is considered to confer virtual protection from viral infection, at least in Phaeocystis pouchetii (Jacobsen et al. 1996, 2005) and perhaps also in P. globosa (Brussaard et al. 2005). Thus a growth strategy that rapidly increases colony size to minimize grazing losses would be evolutionarily advantageous. Young colonies reduce exposure to grazing by microzooplankton compared to free-living cells, but they are still sufficiently small to be ingested by microzooplankton (Jakobsen \& Tang 2002, reviewed in Nejstgaard et al. 2007); at the same time, they are also crossing the minimum size threshold for efficient collection by metazoan zooplankton (Berggreen et al. 1988, Hansen et al. 1994, Verity 2000). The faster small colonies passed through this window of dual grazing susceptibility, the lower their grazing losses would be. From this perspective, the critical issue is the rapid ultradian growth of cells within colonies, rather than the phase of the light cycle during which growth occurs. The enhanced metabolic requirements for carbon and nutrients associated with ultradian growth can be uniquely met within the colony stage of the life cycle. Organic polysaccharides stored in the colony matrix can be used to facilitate nutrient uptake or cell and colony growth during the dark period (Lancelot \& Mathot 1985, Veldhuis \& Admiraal 1985, Veldhuis et al. 1991).

Thus, there may be 2 evolutionary advantages of ultradian growth: rapid numerical and biomass increases, made possible by utilization of the dark period; and reduction in losses to small grazers, an ecological by-product that is independent of the phase of the light:dark cycle. These dual advantages would reduce mortality sufficiently, while growth rates equal or exceed those of solitary cells (Veldhuis et al. 2005), so that colonies can temporarily escape significant biological control of their numbers, and thereby initiate the prodigious blooms for which they are known. This study illustrates that colony bloom development is not necessarily a long, slow conversion of a previously accumulated pool of solitary cells, but reflects briefer periods of rapid formation and growth of new colonies from a small fraction of solitary cells, using a mechanism that may reduce losses of young colonies to grazers. Furthermore, grazing may not only act as an important loss process influencing the size distribution and development of Phaeocystis blooms, but may actually function as a trigger for life cycle changes in this genus (Tang 2003, Verity \& Medlin 2003, Nejstgaard et al. 2007). Coupled with evidence for allelopathic inhibition of competing cells and perhaps even toxic effects (van Rijssel et al. 2007, J. D. Long et al. unpubl.), it is perhaps not at all surprising that this sophisticated alga can so often divert, acquire, and sequester tremendous amounts of euphotic zone nutrients, and thus function as a keystone species in trophic interactions and energy flow (reviewed in Verity et al. 2007).

Acknowledgements. We thank the University of Bergen (UIB) and the staff of the UIB Marine Station who assisted in set-up and maintenance of the laboratory and mesocosm facilities. A. Jacobsen, S. R. Borrett, M. E. Frischer, B. C. Patten, and S. J. Whipple discussed ideas and provided valuable general mesocosm operational and data support. Comments from 2 anonymous reviewers provided the impetus for broader interpretation of the data. Figures were prepared by A. H. Boyette. This research was funded by US National Science Foundation grant OPP-00-83381 and DOE grant FG02-98EF 62531. 


\section{LITERATURE CITED}

Alderkamp AC, Nejstgaard JC, Verity PG, Zirbel MJ, Sazhin AF, van Rijssel M (2006) Dynamics in carbohydrate composition of Phaeocystis pouchetii colonies during spring blooms in mesocosms. J Sea Res 55:169-181

Baumann MEM, Lancelot C, Brandini FP, Sakshaug E, John DM (1994) The taxonomic identity of the cosmopolitan genus Phaeocystis: a morphological and ecological approach. J Mar Syst 5:5-22

Berggreeen U, Hansen B, Kiørboe T (1988) Food size spectra, ingestion, and growth of the copepod Acartia tonsa during development: implications for determination of copepod production. Mar Biol 99:341-352

Boalch GT (1984) Algal blooms and their effects on fishing in the English Channel. Hydrobiologia 116-117:449-452

Brussaard CPD, Kuipers B, Veldhuis MJW (2005) A mesocosm study of Phaeocystis globosa population dynamics. I. Regulatory role of viruses in bloom control. Harmful Algae $4: 859-874$

Cariou V, Casotti R, Birrien JL, Vaulot D (1994) The initiation of Phaeocystis colonies. J Plankton Res 16:457-470

Edmunds LN Jr, Funch R (1969) Effects of 'skeleton' photoperiods and high frequency light-dark cycles on the rhythm of cell division in synchronized cultures of Euglena. Planta (Berlin) 87:134-163

Egge JK (1993) Nutrient control of phytoplankton growth: effects of macronutrient composition $(\mathrm{N}, \mathrm{P}, \mathrm{Si})$ on species succession. $\mathrm{PhD}$ dissertation, University of Bergen

Haas LW (1982) Improved epifluorescence microscopy for observing planktonic micro-organisms. Ann Inst Oceanogr 58:261-266

Hamm CE (2000) Architecture, ecology and biogeochemistry of Phaeocystis colonies. J Sea Res 43:307-315

Hansen B, Bjornsen PK, Hansen PJ (1994) The size ratio between planktonic predators and their prey. Limnol Oceanogr 39:395-403

Jacobsen A (2002) Morphology, relative DNA content and hypothetical life cycle of Phaeocystis pouchetii (Prymnesiophyceae), with special emphasis on the flagellated cell type. Sarsia 87:338-349

Jacobsen A, Veldhuis MJW (2005) Growth characteristics of flagellated cells of Phaeocystis pouchetii revealed by diel changes in cellular DNA content. Harmful Algae 4: 811-821

Jacobsen A, Egge JK, Heimdal BR (1995) Effects of increased concentration of nitrate and phosphate during a springbloom experiment in mesocosm. J Exp Mar Biol Ecol 187: $239-251$

Jacobsen A, Bratbak G, Heldal M (1996) Isolation and characterization of a virus infecting Phaeocystis pouchetii (Prymnesiophyceae). J Phycol 32:923-927

Jacobsen A, Martínez-Martínez J, Verity P, Frischer ME, Sandaa RA Larsen A (2005) Are colonies or colonial cells of Phaeocystis pouchetii (Prymnesiophyceae) susceptible to virus infection? ASLO Summer Meeting, Santiago de Compostela

Jakobsen HH, Tang KW (2002) Effects of protozoan grazing on colony formation in Phaeocystis globosa (Prymnesiophyceae) and the potential costs and benefits. Aquat Microb Ecol 27:261-273

Lancelot C, Mathot S (1985) Biochemical fractionation of primary production by phytoplankton in Belgian coastal waters during short- and long-term incubations with ${ }^{14} \mathrm{C}$ bicarbonate. Mar Biol 86:219-286

Lancelot C, Rousseau V (1994) Ecology of Phaeocystis: the key role of colony forms. In: Green JC, Leadbeater BSC (eds) The haptophyte algae. Clarendon Press, Oxford, p 229-245

Lancelot C, Wassmann P, Barth H (1994) Ecology of Phaeocystis-dominated ecosystems. J Mar Syst 5:1-4

Nejstgaard JC, Frischer ME, Verity PG, Anderson JT and 11 others (2006) Plankton development and trophic transfer in seawater enclosures with nutrients and Phaeocystis pouchetii added. Mar Ecol Prog Ser 321:99-121

Nejstgaard JC, Tang KW, Steinke M, Dutz J, Koski M, Antajan E, Long JD (2007) Zooplankton grazing on Phaeocystis: a quantitative review and future challenges. Biogeochemistry 83:147-172

Peperzak L, Colijn F, Vrieling EG, Gieskes WWC, Peeters $\mathrm{JCH}$ (2000) Observations of flagellates in colonies of Phaeocystis globosa (Prymnesiophyceae); a hypothesis for their position in the life cycle. J Plankton Res 22: 2181-2203

Porter KG, Feig YS (1980) The use of DAPI for identifying and counting aquatic microflora. Limnol Oceanogr 25:943-948

Rousseau V, Vaulot D, Casotti R, Cariou V, Lenz J, Gunkel J, Baumann M (1994) The life cycle of Phaeocystis (Prymnesiophyceae): evidence and hypotheses. J Mar Syst 5:23-39

Rousseau V, Chrétiennot-Dinet MJ, Jacobsen A, Verity P, Whipple S (2007) The life cycle of Phaeocystis: state of knowledge and presumptive role in ecology. Biogeochemistry 83:189-200

Savage RE (1930) The influence of Phaeocystis on the migrations of the herring. Fish Invest Ser II 12:1-14

Schoemann V, Becquevort S, Stefels J, Rousseau V, Lancelot C (2005) Phaeocystis blooms in the global ocean and their controlling mechanisms: a review. J Sea Res 53:43-66

Shalapyonok A, Olson RJ, Shalapyonok LS (1998) Ultradian growth in Prochlorococcus spp. Appl Environ Microbiol 64:1066-1069

Tang KW (2003) Grazing and colony size development in Phaeocystis globosa (Prymnesiophyceae): the role of a chemical signal. J Plankton Res 25:831-842

van Rijssel M, Hamm CE, Gieskes WWC (1997) Phaeocystis globosa (Prymnesiophyceae) colonies: hollow structures built with small amounts of polysaccharides. Eur J Phycol 32:185-192

van Rijssel M, Alderkamp AC, Nejstgaard JC, Sazhin AF, Verity PG (2007) Haemolytic activity of living Phaeocystis pouchetii during mesocosm blooms. Biogeochemistry 83:189-200

Veldhuis MJW, Admiraal W (1985) Transfer of photosynthetic products in gelatinous colonies of Phaeocystis pouchetii (Haptophyceae) and its effect on the measurement of excretion rate. Mar Ecol Prog Ser 26:301-304

Veldhuis MJW, Colijn F, Admiraal W (1991) Phosphate utilization in Phaeocystis pouchetii (Haptophyceae). Sci Mar 12:53-62

Veldhuis MJW, Brussard C, Noordeloos A (2005) Living in a Phaeocystis colony; a way to be a successful algal species. Harmful Algae 4:841-858

Verity PG (2000) Grazing experiments and model simulations of the role of zooplankton in Phaeocystis food webs. J Sea Res 43:317-343

Verity PG, Medlin LK (2003) Observations on colony formation by the cosmopolitan phytoplankton genus Phaeocystis. J Mar Syst 43:153-164

Verity PG, Villareal TA, Smayda TJ (1988) Ecological investigations of blooms of colonial Phaeocystis pouchetii. II. The role of life cycle phenomena in bloom termination. J Plankton Res 10:749-766

Verity PG, Brussaard CP, Nejstgaard JC, van Leeuwe M, Lancelot M, Medlin LK (2007) Current understanding of 
Phaeocystis ecology and biogeochemistry, and perspectives for future research. Biogeochemistry 83:311-330

Whipple SJ, Patten BC, Verity PG (2005) Colony growth and evidence for colony multiplication in Phaeocystis pouchetii (Prymnesiophyceae) isolated from mesocosm blooms. J Plankton Res 27:495-501

Editorial responsibility: Edna Granéli, Kalmar, Sweden
Whipple SJ, Patten BC, Verity PG, Frischer ME and 7 others (2007) Gaining integrated understanding of Phaeocystis spp. (Prymnesiophyceae) through model-driven laboratory and mesocosm studies. Biogeochemistry 83:293-309 Williams PJLeB, Egge JK (1998) The management and behaviour of the mesocosms. Estuar Coast Shelf Sci 46:3-14

Submitted: July 31, 2006; Accepted: January 29, 2007

Proofs received from author(s): May 12, 2007 